\title{
Bacteriological Assessement of Vegetables Cultivated in Soils Treated with Poultry Manure and the Manure- Treated Soil Samples
}

\author{
OBI C. N. \\ Department of Microbiology, College of Natural Sciences, Michael Okpara University of Agriculture, Umudike, Umuahia, Abia State, \\ Nigeria \\ *Corresponding author: b4brocliff@gmail.com
}

Received October 16, 2014; Revised November 08, 2014; Accepted November 11, 2014

\begin{abstract}
Bacteriological quality of four vegetables: waterleaf (W), pumpkin (P), cucumber (C) and tomatoes (T) cultivated in soils treated with poultry manure and the manure-treated soil samples (S1, S2, S3 and S4) were assessed using standard microbiological methods. Escherichia coli, Staphylococcus aureus, Klebsiella spp., Bacillus spp, Salmonella spp. and Shigella spp were recovered from the soil and vegetable samples. The total bacterial count of the soil samples ranged from $1.75 \times 10^{9}$ (S3) to $5.9 \times 10^{4} \mathrm{cfu} / \mathrm{ml}$ (S4) while the total bacterial count for the vegetable samples ranged from $2.65 \times 10^{9}(\mathrm{P})$ to $1.50 \times 10^{5} \mathrm{cfu} / \mathrm{ml}(\mathrm{W})$. The total coliform count of the soil samples ranged from $1.65 \times 10^{7}(\mathrm{~S} 3)$ to $6.9 \times 10^{4} \mathrm{cfu} / \mathrm{ml}$ (S4) while that of the vegetable samples ranged from $1.20 \times 10^{8}(\mathrm{P})$ to $7.2 \times 10^{5} \mathrm{cfu} / \mathrm{ml}$ (W). S1 was significantly different from S2 and S4 for the total bacteria count for the soil samples while P and W were significantly different for the vegetable samples $(\mathrm{P}<0.05)$. For Salmonella-Shigella plate counts, $\mathrm{S} 1$ and $\mathrm{S} 4$ were significantly different and S2 and S3 were same $(\mathrm{P}<0.05)$; while for the vegetable samples, $\mathrm{P}, \mathrm{W}, \mathrm{C}$ and $\mathrm{T}$ were significantly different $(\mathrm{P}<0.05)$. S1, S2, S3, and S4 were significantly different for the total coliform count for the soil samples and same for $\mathrm{P}, \mathrm{W}$ and $\mathrm{C}(\mathrm{P}<0.05)$. Sensitivity screening for the isolates showed that Bacillus spp was most sensitive to Ofloxacin (25mm) while Staphylococcus aureus was most sensitive to Ofloxacin (22mm). Shigella was most sensitive to Ciprofloxacin (25mm) while E. coli showed highest sensitivity to Ciproflacin (25mm) and Ofloxacin (25mm). In addition, Klebsiella spp was most sensitive to Ciprofloxacin (23mm) and Ofloxacin (23mm) and Salmonella showed resistance to all the antibiotics. This study demonstrated that there is a high level of microbial contamination associated with the cultivation of vegetables in soils in which organic manure has been applied to which is of risk to the consumers.
\end{abstract}

Keywords: bacterial pathogens, contamination, poultry manure, soil, vegetables

Cite This Article: OBI C. N., "Bacteriological Assessement of Vegetables Cultivated in Soils Treated with Poultry Manure and the Manure-Treated Soil Samples.” American Journal of Microbiological Research, vol. 2, no. 6 (2014): 189-200. doi: 10.12691/ajmr-2-6-5.

\section{Introduction}

Raw and minimally-processed vegetables are an essential part of people's diet all around the world because they serve as an extraordinary dietary source of nutrients, micronutrients, vitamins and fibre for humans and are thus vital for health and well being. Well balanced diets, rich in fruits and vegetables, are especially valuable for their ability to prevent vitamin $\mathrm{C}$ and A deficiencies and are also reported to reduce the risk of several diseases (Kalia and Gupta, 2006).

Vegetables are widely exposed to microbial contamination through contact with soil, dust and water and by handling at harvest or during postharvest processing. They therefore harbour a diverse range of microorganisms including plant and human pathogens (Carmo et al., 2004). Vegetable consumption has been associated with a reduced risk for cardiovascular disease
(Djoussé et al., 2004; John and Ziebland, 2004), cancer (Riboli and Norat, 2003), stroke, and reduced mortality. Differences in microbial profiles of various vegetables result largely from unrelated factors such as resident microflora in the soil, application of nonresident microflora via animal manures, sewage or irrigation water, transportation and handling by individual retailers (Ray and Bhunia 2007; Ofor et al., 2009).

In developing countries such as Nigeria, continued use of untreated waste water and manure as fertilizers for the production of fruits and vegetables is a major contributing factor to contamination (Amoah et al., 2009). Despite their nutritional and health benefits, outbreaks of human infections associated with the consumption of fresh or minimally processed fruits and vegetables have increased in recent years (Beuchat, 2002). Enteric pathogens such as Escherichia coli, Salmonella and Shigella are among the greatest concerns during food-related outbreaks (Buck et al., 2003). Several cases of typhoid fever outbreak have 
been associated with eating contaminated vegetables grown in or fertilized with contaminated soil or sewage (Beuchat, 1998). These increases in fruits and vegetable borne infections may have resulted from increased consumption of contaminated fruits and vegetables both in the home and outside the home as most people spend long hours outside the home. In Nigeria for instance, street vending of handy ready-to-eat sliced fruit and vegetables has recently become very common and the market is thriving.

Even though vegetables have caught the eyes of many vegetable growers' attention in the world, the serious implication relating to the use of organic manure in the fertilization of vegetables has led to an increasing health problem as a result of contamination of vegetables by microorganisms (Maboko and Du Plooy, 2008).

\section{Objectives of Research}

Increased consumption of vegetables has increased their demand for these products which has led to an alarming increase associated with the negative health implication associated with consumption of contaminated batches of vegetables produced from soils treated with animal manure. This research work carried out in 2014 aimed at:

i. determining the microorganisms associated with selected vegetables cultivated in soil treated with poultry manure and the manure-treated soil samples;

ii. determining the antimicrobial susceptibility patterns of the isolates.

\section{Soil Sampling and Analysis}

Ten grams ( $10 \mathrm{~g})$ of soil surrounding a randomly selected vegetable plant at a depth of $2.5 \mathrm{~cm}$ from the surface were aseptically collected from each treated plot of farmland for each crop using a sterile trowel previously sprayed with $70 \%$ ethanol. The samples were kept in a sterile plastic bag and transported to the laboratory for analysis. This collection was replicated four times four times for each vegetable sample.

One gram (1g) of each soil sample was serially diluted with $9 \mathrm{ml}$ of distilled water in eight test tubes. $0.1 \mathrm{ml}$ aliquot of the serially diluted samples (from $10^{-4}$ to $10^{-6}$ ) was spread plated on MacConkey agar (Titan, Biotech limited), Salmonella-Shigella agar (Titan Biotech limited), and Nutrient agar (Titan Biotech limited). The plates were incubated at $25^{\circ} \mathrm{C}$ for 24 hours for bacterial growth.

\section{Vegetable Sampling and Analysis}

Samples of four vegetables: Waterleaf (W), Pumpkin (P), Cucumber (C) and Tomatoes (T) samples were randomly selected from plants thinned or harvested and the edible portions (root for cucumber, fruit for tomatoes and leaves for pumpkin and water leaf) were separated using scissors previously sprayed with $70 \%$ ethanol, placed in sterile plastic bags and transported to the laboratory for analysis within one hour. The vegetables were sampled four times. MacConkey agar (Titan Biotech limited), Salmonella-Shigella agar (Titan Biotech limited) and Nutrient agar (Titan Biotech limited) were prepared according to manufacturer's instruction, and sterilized by autoclaving at $121^{\circ} \mathrm{C}$ for 15 minutes except SalmonellaShigella agar which does not require autoclaving and was sterilized by boiling for 15 minutes.

Ten grams (10g) of each vegetable sample were weighed with a weighing balance and rinsed thoroughly in $90 \mathrm{ml}$ of distilled water. $1 \mathrm{ml}$ of the rinse water was then serially diluted $(1: 10)$ in six test tubes and $0.1 \mathrm{ml}$ aliquot from $10^{-3}$ and $10^{-4}$ dilutions were spread onto the various agar for determination of bacteria and incubated aerobically and anaerobically at $37^{\circ} \mathrm{C}$ for 24 hours. The total number of colonies that developed were counted (30300 colonies), and expressed as CFU/ml for microbial load. Colonies were differentiated on the basis of morphological and counts were made for the different colonies. Pure cultures of representative bacterial colonies were obtained by sub-culturing by streaking onto sterile Nutrient agar, MacConkey agar, and Salmonella- Shigella agar plates previously prepared. The plates were then incubated at $37^{\circ} \mathrm{C}$ for 24 hours. Isolated colonies resulting from these cultures were examined with respect to colony features such as consistency, edge of colony, extent of growth, and pigmentation and was preserved on agar slants and subjected to Gram reaction and other biochemical tests (Baker and Breach, 1980; Cowan and Steel, 1985).

\section{Biochemical Tests}

The isolates were from the soil and vegetable samples analyzed were subjected to biochemical tests: catalase production, oxidase production, indole test, coagulase test and sugar fermentations.

\subsection{Antibiotic Susceptibility Testing}

\subsubsection{Preparation of Turbidity Standard Equivalent to McFarland 0.5}

One percent $(1 \%) \mathrm{v} / \mathrm{v}$ solution of sulphuric acid was prepared by adding $1 \mathrm{ml}$ of concentrated sulphuric acid to $99 \mathrm{ml}$ of water. $1 \%$ of barium chloride was also prepared by dissolving $0.5 \mathrm{~g}$ of dehydrated barium chloride in $50 \mathrm{ml}$ of distilled water. $0.6 \mathrm{ml}$ of Barium chloride solution was added to $99.4 \mathrm{ml}$ of the sulphuric acid solution and mixed properly. The solution was preserved in the fridge.

\subsection{Sensitivity Testing}

The Kirby-Bauer disc diffusion technique was used (CLSI, 2009). Pure colonies of isolates were obtained from agar slants and sub-cultured on already prepared culture plates. After growth within 24hours, isolates from each of the plates were adjusted to 0.5 McFarland standards in $0.9 \%$ saline. Swab sticks were dipped into the solution of the isolate and normal saline and streaked uniformly on Muller-Hinton agar plates to obtain confluent growth. Multi antibiotics sensitivity discs were placed on the surface of the media, using a pair of forceps, little force was applied to ensure firm contact with agar plate. The plates were then inverted and incubated aerobically at $37^{\circ} \mathrm{C}$ for 18 -24hours. 


\section{Measurement of Zone of Inhibition}

The plates were examined for zone of inhibition. Using a ruler, the diameter of zone of inhibition was obtained in millimeters from the reverse of the plate. The zone sizes of each plate (both Gram positive and negative plates) were interpreted and zone sizes reported as susceptible, intermediate or resistant.

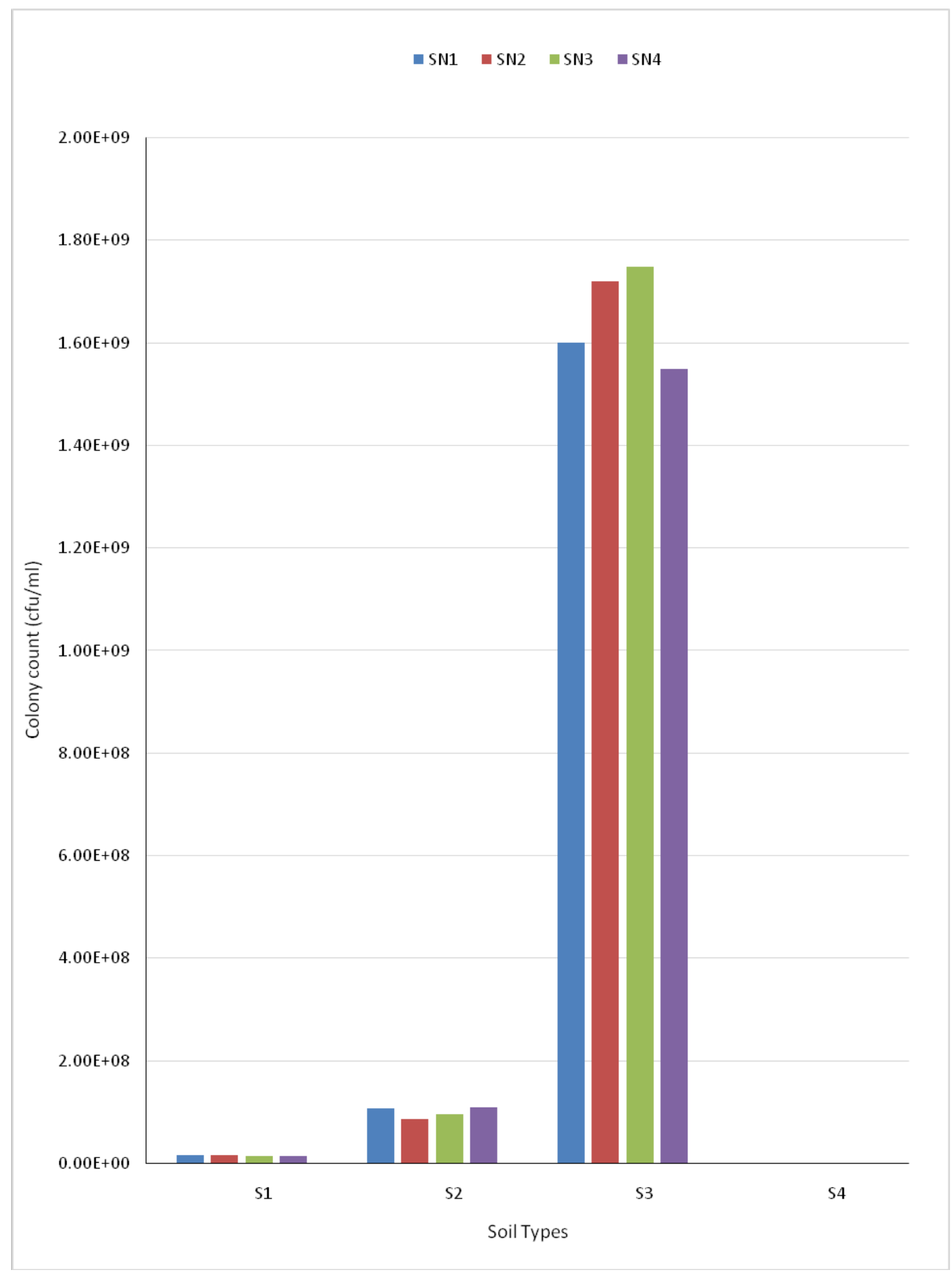

Figure 1. Viable plate count of Microorganisms for experimental soil samples

\section{Results and Discussion}

The analysis was conducted using four vegetable types and four soil samples for the respective vegetables namely: Pumpkin (coded P and S1 for the cultivated soil of pumpkin); Water leaf (coded W and S2 for the cultivated soil of water leaf), Cucumber (coded C and S3 for the cultivated soil) and Tomatoes (coded T and S4 for the cultivated soil). Staphylococcus aureus, Escherichia coli, Klesbsiella spp, Shigella spp., Salmonella spp, and Bacillus spp recovered from the vegetable and soil samples. The colony forming unit $(\mathrm{cfu} / \mathrm{ml})$ values are shown in Figure 1, Figure 2, Figure 3, Figure 4, Figure 5, Figure 6, Figure 7 and Figure 8 while Table 1 and Table 2 show the antibiotic sensitivity patterns for the Gram positive and Gram negative organisms respectively. 


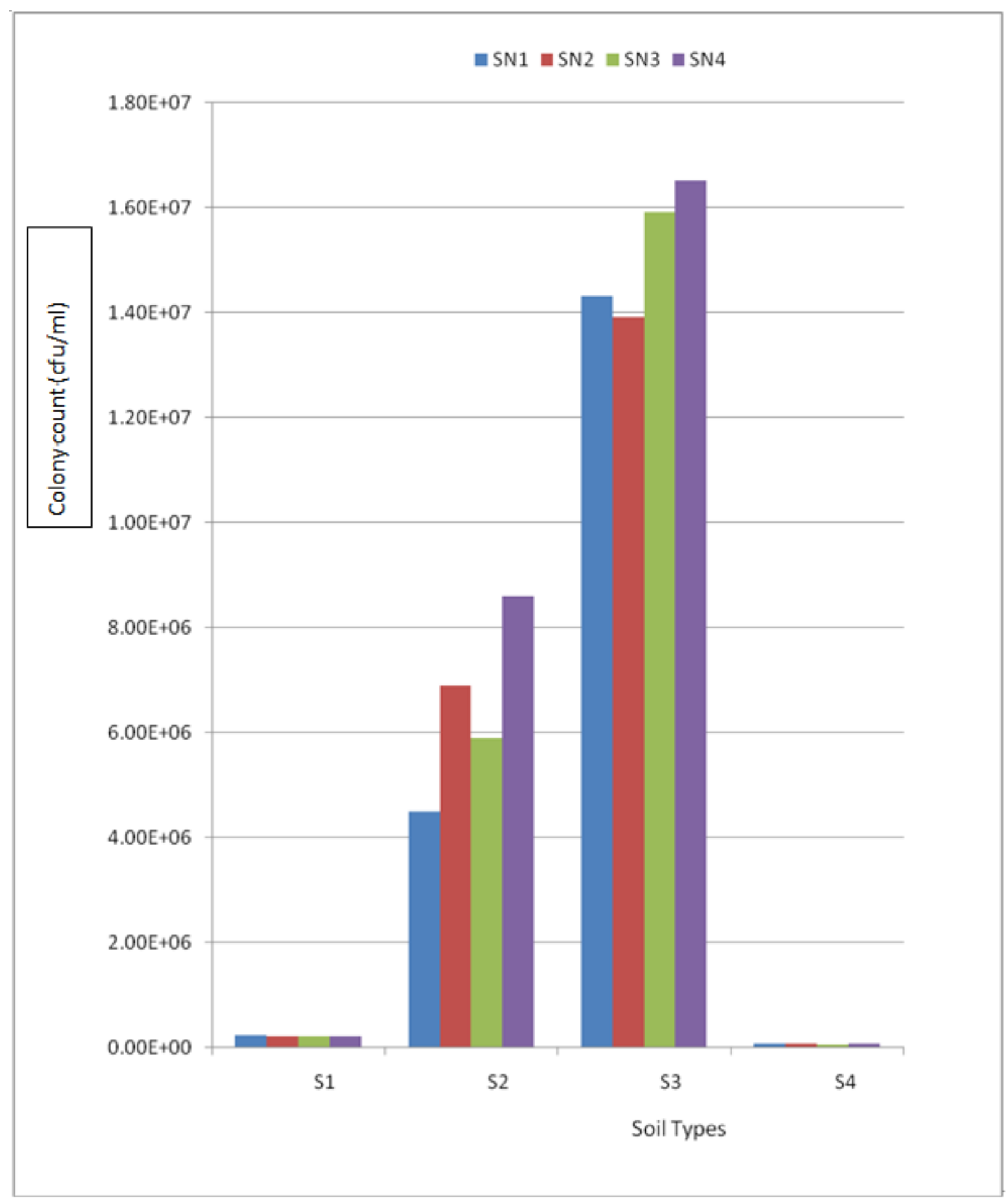

Figure 2. Total Coliform Count for the experimental soil samples

This study has shown that the application of poultry manure to soil cultivated with some ready-to-eat vegetables is of great microbial hazard. Therefore, vegetables may act as a reservoir for several pathogens and thereafter infect susceptible host (Beuchat, 1998). Almost any ready-to-eat vegetable that has been contaminated with pathogens either from the environment or from human or animal faeces or through storage, processing and handling could potentially cause disease (Beuchat, 2002).

The high Total bacterial and coliform counts, detected among the vegetable samples surveyed in this investigation revealed that the contamination of these vegetables by pathogenic microorganisms may present a potential health hazard to consumers. The Total bacteria count which ranged from $1.75 \times 10^{9} \mathrm{cfu} / \mathrm{ml}$ to $5.9 \times 10^{4} \mathrm{cfu} / \mathrm{ml}$ and $2.65 \times 10^{9} \mathrm{cfu} / \mathrm{ml}$ to $1.50 \times 10^{5} \mathrm{cfu} / \mathrm{ml}$ for the soil and vegetable samples respectively showed that a diverse population of bacteria can be isolated from vegetables and soil used in cultivating them. In comparison with the work carried out by Macklin et al., (2005), it is believed that the countable colonies fell in between $10^{4}$ to $10^{9} \mathrm{cfu} / \mathrm{ml}$ due to environmental factors affecting the soil and its constituent, competition between residual microorganisms which was not present in the fresh poultry manure. 


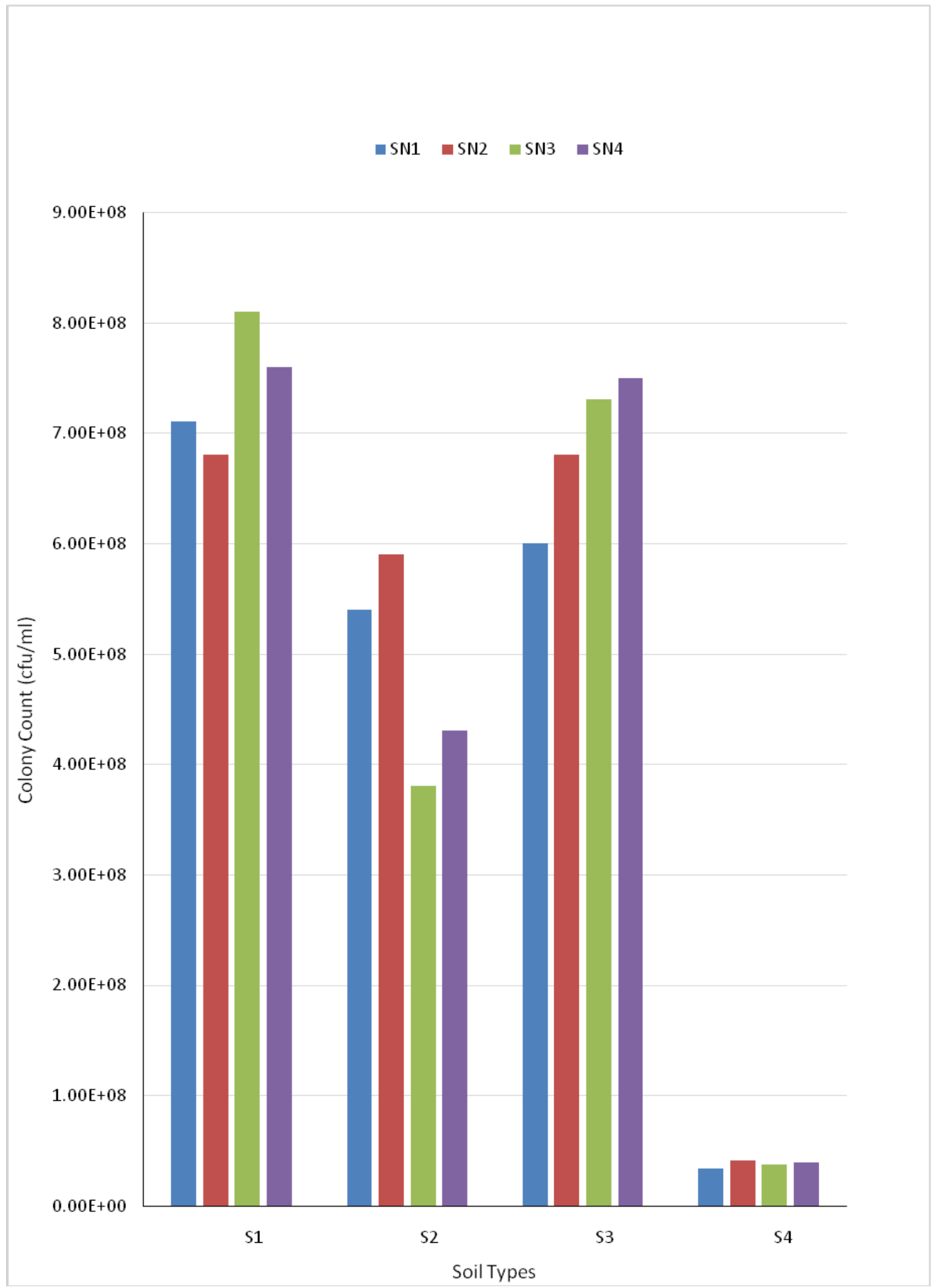

Figure 3. Total anaerobic bacteria count of the experimental soil samples

The Total coliform count which ranged from $1.65 \times 10^{7}$ $6.9 \times 10^{4} \mathrm{cfu} / \mathrm{ml}$ and $1.20 \times 10^{8}-7.2 \times 10^{5} \mathrm{cfu} / \mathrm{ml}$ showed that both the vegetable and soil harbored enteric organisms of faecal origin. Fruits and vegetables can become contaminated with pathogenic microorganisms during harvesting through faecal material, human handling, harvesting equipment, transport containers, wild and domestic animals, air, transport vehicles, ice or water (Beuchat, 1995).

The presence of high number of total coliform (Klebsiella) and faecal coliform (Escherichia coli) in the soil and vegetable samples revealed that the manure could 
be a possible source of contamination from the soil to the vegetable. Kudva et al., (1998) confirmed the occurrence of E. coli and other coliforms in birds used as poultry. $S$. aureus which is a chance contaminant was also detected. According to Houang et al., (1991), there have been occurrences of $S$. aureus on ready-to-eat vegetables. Although $S$. aureus may have a diverse route in terms of contamination of vegetables viz the nasal passages of healthy food handlers and by irrigation of vegetable farm with contaminated water (Abdelnoor et al., 1983).

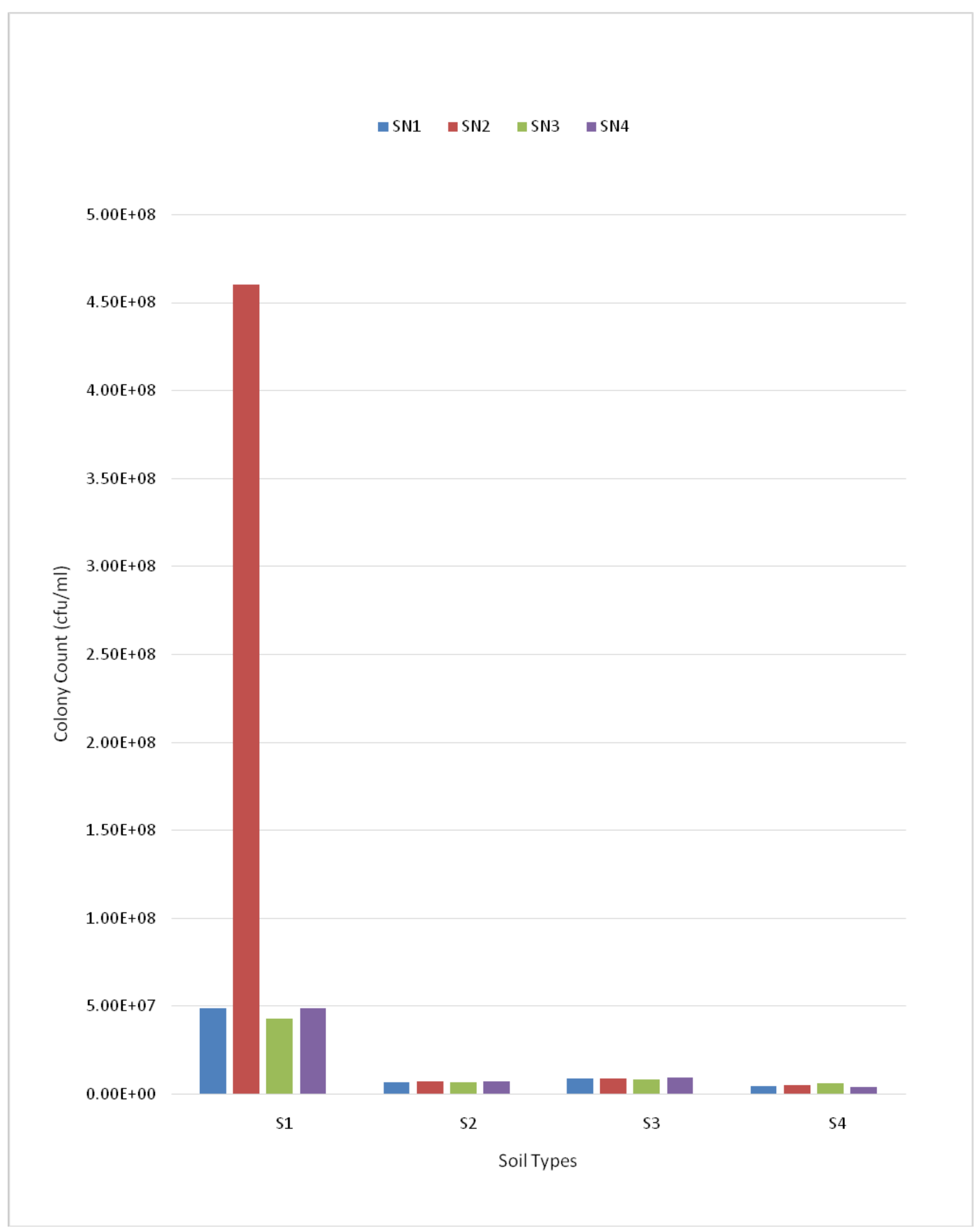

Figure 4. Total plate count for Salmonella and Shigella of the four experimental soil samples

Contamination of the different soil samples and vegetables like cucumber and watermelon by Bacillus spp was also noted. These medium (soil and rooted vegetables) provide an anaerobic environment that favours the growth of Bacillus subtilis (Solomon et al., 1990). Salmonella and
Shigella contamination was also prominent in all the vegetable and soil samples analyzed. This posses a possible means of transfer from manure to soil and then to vegetable. The contamination by these species of organisms is believed to be through this route due to the 
observation that the climate, soil conditions and growing practices failed to influence contamination. According to Frehund et al., (1987) several large outbreaks of Shigellosis have been attributed to the consumption of contaminated raw fruits and vegetables. An outbreak of
Salmonella in 1974 was attributed to watermelon that was contaminated with Salmonella typhimurium that had been collected from the ground, which had been fertilized with cow and poultry manure (Fisher and Golden, 1998).

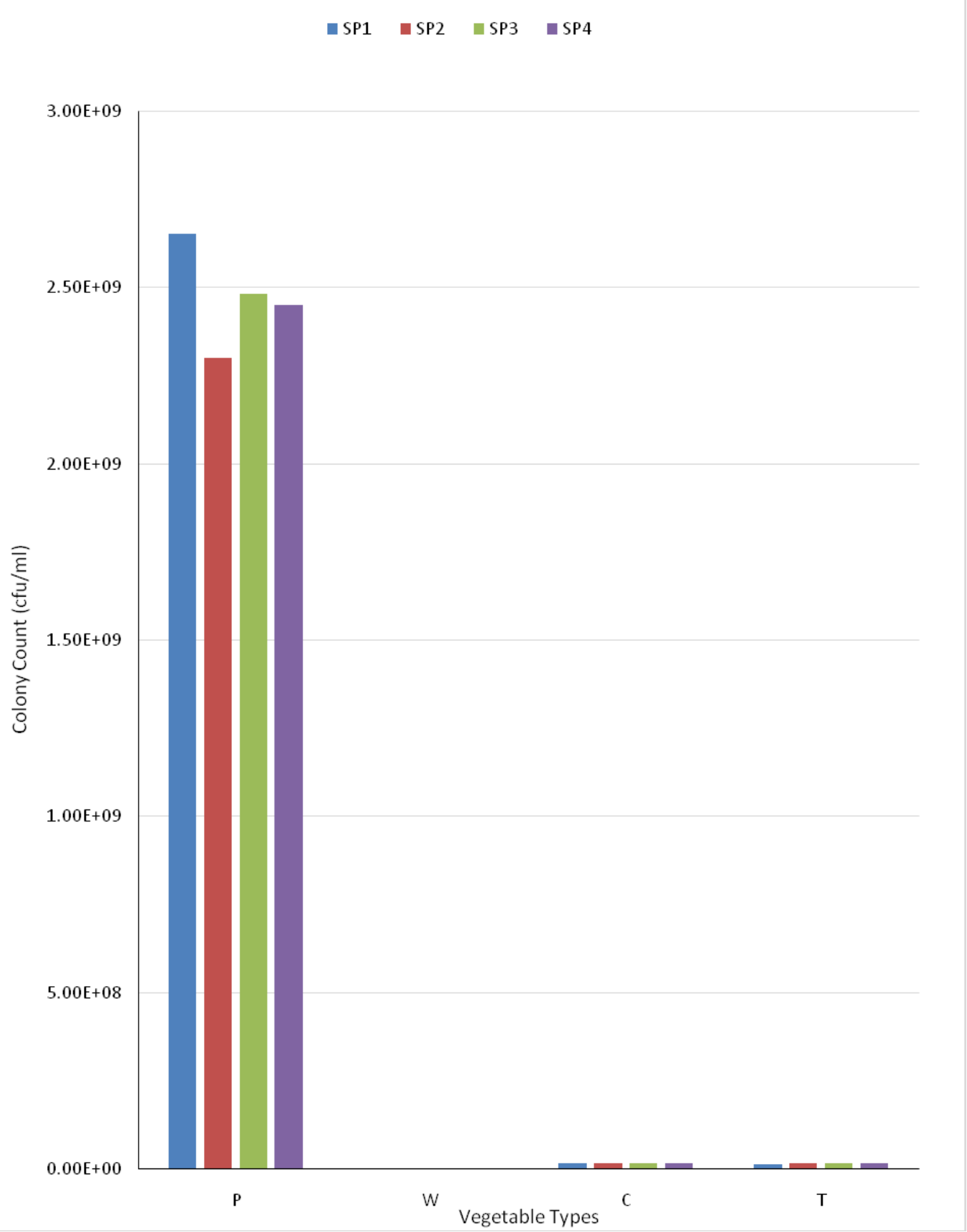

Figure 5. Viable plate count of Microorganisms for experimental vegetable samples

According to Schefferle, (1995) total litter bacteria concentration fall within the range of $10^{10}$ to $10^{11}$ colony forming units (cfu) per gram of litter. Total aerobic counts of poultry manure are lower at $10^{8}$ to $10^{10}$ (Macklin et al.,
2005). These earlier investigation matched this study based on the fact that most of the aerobic plate count produced high bacterial population at concentrations ranging $10^{7}$ to $10^{9}$ but the bacterial count in relation to 
some of the soil and vegetable analyzed fell at concentrations between $10^{4}$ to $10^{6}$. This variation in bacterial count is believed to be as a result of the type of vegetable analyzed example cucumber is a root vegetable in which the edible portion is in close proximity with the soil in which manure has been applied to. This accounts for the high bacteria count gotten from the analysis of this vegetable.

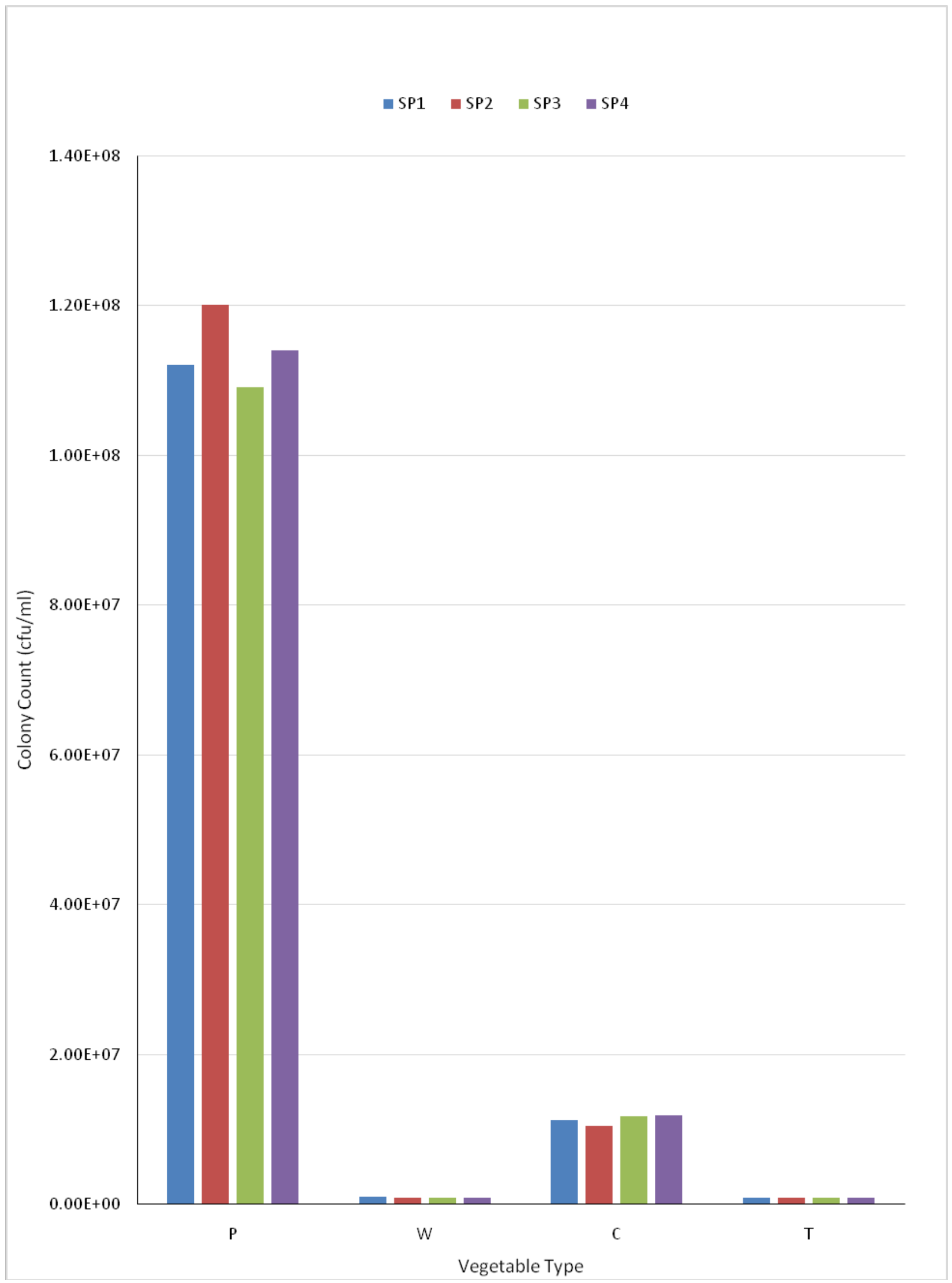

Figure 6. Total Coliform count of the experimental vegetable samples

Antibiotic sensitivity screening showed that Bacillus subtillis was most sensitive to Ofloxacin (25mm) and sensitive to Gentamycin (21mm) but had an intermediate susceptibility to Ceftriaxone $(16 \mathrm{~mm})$. However, it was 
resistant to other antibiotics tested. S. aureus was most sensitive to Ofloxacin $(22 \mathrm{~mm})$, then to Gentamycin (16mm) and intermediately susceptible to Ceftriaxone (15mm) but resistant to other antibiotics tested.

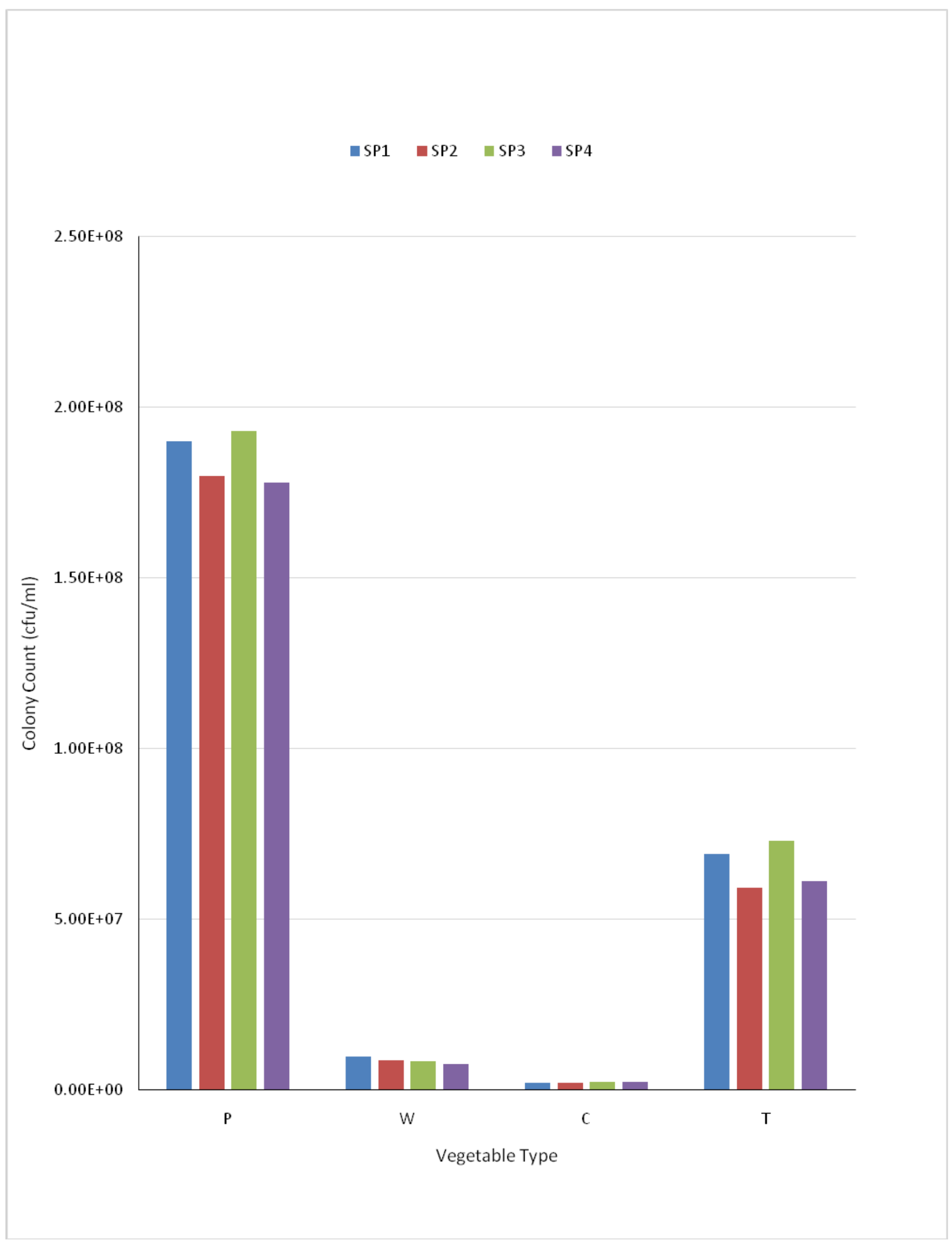

Figure 7. Total Anaerobic Bacteria Count of the experimental vegetable samples

Among all the Gram negative organisms isolated, Shigella spp was most sensitive to Ciprofloxacin (25mm), sensitive to Gentamycin (20mm), intermediately sensitive to Nitroxoline $(15 \mathrm{~mm})$ but resistant to other antibiotics tested. Salmonella spp showed resistance to all the antibiotics. E. coli showed high sensitivity to Ciprofloxacin, Ofloxacin, Gentamycin and Nitroxoline antibiotics with inhibitory zones of $25 \mathrm{~mm}, 25 \mathrm{~mm}, 23 \mathrm{~mm}$, 
and $21 \mathrm{~mm}$ respectively and resistant to other antibiotics. Klebsiella spp was most sensitive to Ciprofloxacin and Ofloxacin with inhibitory zones of $23 \mathrm{~mm}$ and $23 \mathrm{~mm}$ and sensitive to Gentamycin at inhibitory zone of $22 \mathrm{~mm}$. However, it was resistant to Nitroxoline and other antibiotics contained in the disc tested.

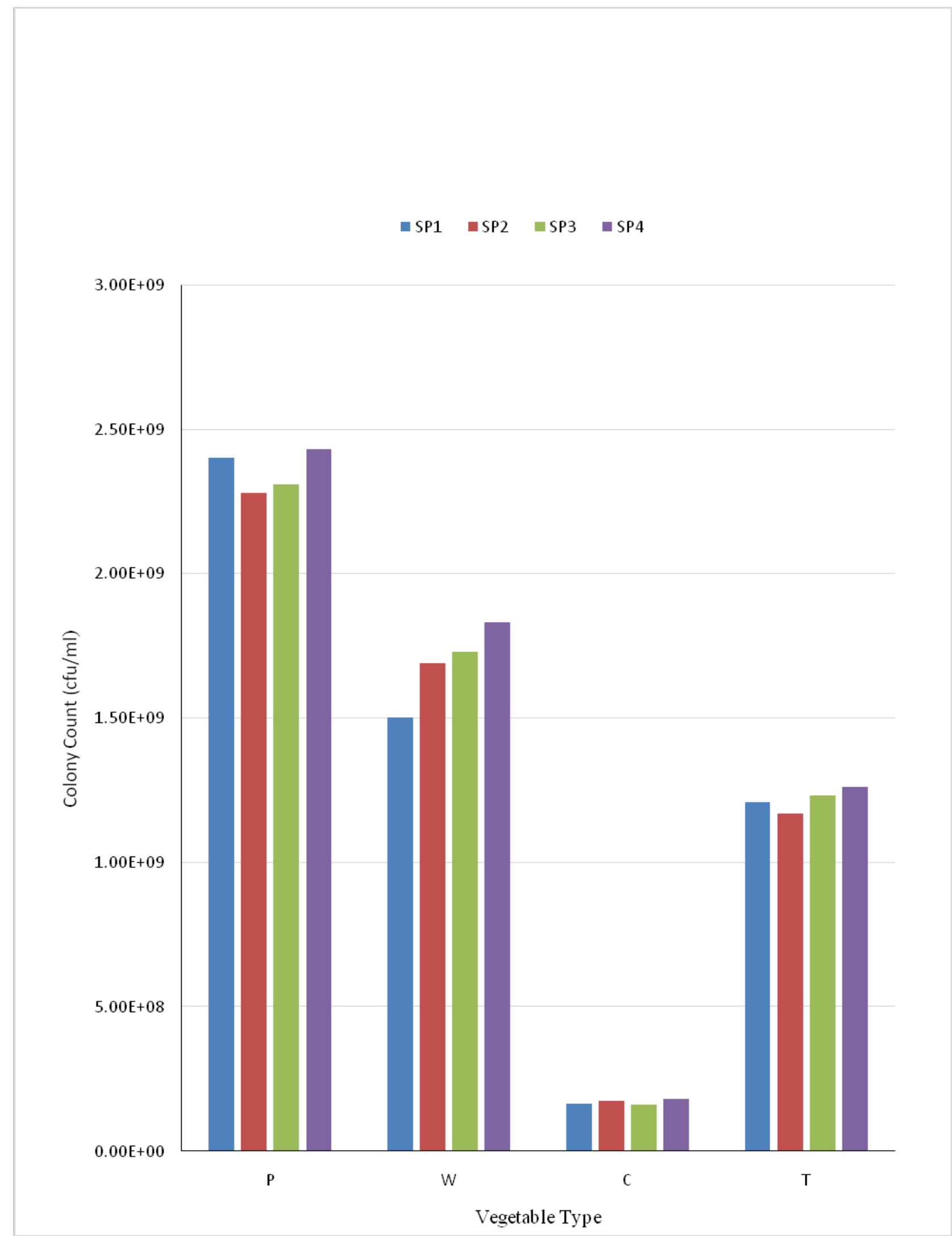

Figure 8. Total Plate Count for Salmonella and Shigella of the four experimental vegetable samples

From this study, it is deducted that diverse bacterial populations are associated with the soil and vegetable samples analyzed. In developing countries like Nigeria, the continued use of untreated or not-well-treated waste water and manure as fertilizers for the production of fruits and vegetables is a major contributing factor to microbial contamination (Amoah et al, 2009). 
Table 1. Antibiotic Sensitivity pattern of Gram Positive Isolates (mm)

\begin{tabular}{|c|c|c|c|c|c|c|c|c|}
\hline Grain positive & 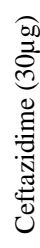 & 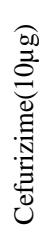 & 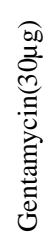 & 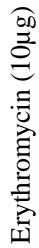 & 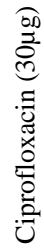 & 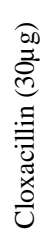 & 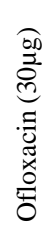 & 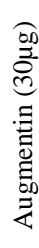 \\
\hline Bacillus spp & $\mathrm{R}$ & $\mathrm{R}$ & 21 & $\mathrm{R}$ & 16 & $\mathrm{R}$ & 25 & $\mathrm{R}$ \\
\hline $\begin{array}{c}\text { Staphylococcus } \\
\text { aureus }\end{array}$ & $\mathrm{R}$ & $\mathrm{R}$ & 16 & $\mathrm{R}$ & 15 & $\mathrm{R}$ & 22 & $\mathrm{R}$ \\
\hline
\end{tabular}

Key: Cfz- Ceftazidime, Crx- Cefurizime, Gen- Gentamycin, Ery-

Erythromycin, Cxc-Cloxacillin, Ofl-Ofloxacin, Aug-Augmentin, Cpr-

Ciprofloxacin. R = Resistant.

INTERPRETATIVE REFRENCE RANGE

$\begin{array}{lccc}\text { CODE } & \text { SENSITIVE } & \text { INTERMEDIATE } & \text { RESISTANT } \\ \text { Cfz } & \geq 18 & 11-15 & \leq 10 \\ \text { Crx } & \geq 17 & 12-16 & \leq 11 \\ \text { Gen } & \geq 15 & 13-14 & \leq 12 \\ \text { Cpr } & \geq 19 & 2-18 & \leq 11 \\ \text { Ery } & \geq 23 & 14-22 & \leq 13 \\ \text { Cxc } & \geq 14 & 10-13 & \leq 9 \\ \text { Ofl } & \geq 22 & 14-21 & \leq 13 \\ \text { Aug } & \geq 15 & 13-14 & \leq 13\end{array}$

Table 2. Antibiotic Sensitivity pattern of Gram Negative isolates (mm)

\begin{tabular}{|c|c|c|c|c|c|c|c|c|}
\hline Grain negative & 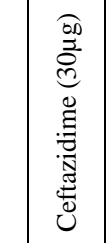 & 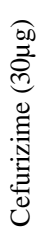 & 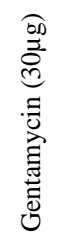 & 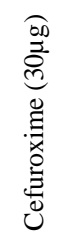 & 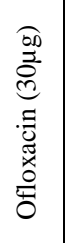 & 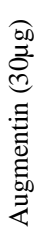 & 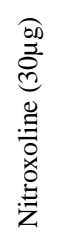 & 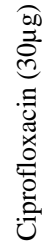 \\
\hline Shigella spp & $\mathrm{R}$ & $\mathrm{R}$ & 20 & $\mathrm{R}$ & 21 & $\mathrm{R}$ & 15 & 25 \\
\hline Salmonella spp & $\mathrm{R}$ & $\mathrm{R}$ & $\mathrm{R}$ & $\mathrm{R}$ & 5 & $\mathrm{R}$ & $\mathrm{R}$ & 8 \\
\hline Escherichia coli & $\mathrm{R}$ & $\mathrm{R}$ & 23 & $\mathrm{R}$ & 25 & $\mathrm{R}$ & 21 & 25 \\
\hline Klebsiella spp & $\mathrm{R}$ & $\mathrm{R}$ & 22 & $\mathrm{R}$ & 23 & $\mathrm{R}$ & 11 & 23 \\
\hline \multicolumn{9}{|c|}{$\begin{array}{l}\text { Key: Cfz- Ceftazidime, Crx- Cefurizime, Gen- Gentamycin, Cxm- } \\
\text { Cefuroxime, Ofl-Ofloxacin, Aug-Augmentin, Nit-Nitroxoline, Cpr- } \\
\text { Ciprofloxacin. R= Resistant. }\end{array}$} \\
\hline \multicolumn{9}{|c|}{ INTERPRETATIVE REFRENCE RANGE: } \\
\hline CODE & \multicolumn{2}{|c|}{ SENSITIVE } & \multicolumn{3}{|c|}{ INTERMEDIATE } & \multicolumn{3}{|c|}{ RESISTANT } \\
\hline $\mathrm{Cfz}$ & \multicolumn{2}{|l|}{$\geq 18$} & \multicolumn{3}{|c|}{$11-15$} & \multicolumn{3}{|c|}{$\leq 10$} \\
\hline Crx & \multicolumn{2}{|l|}{$\geq 17$} & \multicolumn{3}{|c|}{$12-16$} & \multicolumn{3}{|c|}{$\leq 11$} \\
\hline Gen & \multicolumn{2}{|l|}{$\geq 15$} & \multicolumn{3}{|c|}{$13-14$} & \multicolumn{3}{|c|}{$\leq 12$} \\
\hline Cxm & \multicolumn{2}{|l|}{$\geq 23$} & \multicolumn{3}{|c|}{$15-22$} & \multicolumn{3}{|c|}{$\leq 14$} \\
\hline Ofl & \multicolumn{2}{|l|}{$\geq 22$} & \multicolumn{3}{|c|}{$14-21$} & \multicolumn{3}{|c|}{$\leq 13$} \\
\hline Aug & \multicolumn{2}{|l|}{$\geq 15$} & \multicolumn{3}{|c|}{$13-14$} & \multicolumn{3}{|c|}{$\leq 13$} \\
\hline Nit & \multicolumn{2}{|l|}{$\geq 17$} & \multicolumn{3}{|c|}{$15-16$} & \multicolumn{3}{|c|}{$\leq 14$} \\
\hline Cpr & \multicolumn{2}{|l|}{$\geq 21$} & \multicolumn{3}{|c|}{$16-20$} & \multicolumn{3}{|c|}{$\leq 15$} \\
\hline
\end{tabular}

\section{Conclusion}

The present study revealed that several pathogenic bacteria were involved in the contamination of vegetables and this is of high potential hazard to consumers especially the illiterate majority who are not aware of such risks and can go ahead to consume these vegetables without as much as washing them thoroughly. Due to the potential microbiological risks, the safety of these products can be improved by treatment of vegetables with certain surface disinfectants before consumption. Surface disinfectants like chlorine, hydrogen peroxide, ozone, chlorine dioxide can be used in combination with water for treatment of vegetables before consumption. Other methods like irradiation can be used to inactivate pathogens in ready-to-eat vegetables. Antibiotics ranging from; Gentamycin, Ofloxacin, Ciprofloxacin and Nitroxoline can also be used to treat the diseases in which these organisms cause. Organic fertilizers should be treated by composting to reduce the residual microorganisms. Water used in the production, irrigation and washing of vegetables should be of a good quality that does not introduce microorganisms at a level that might cause harm to the consumers.

Finally, harvesting at the appropriate time and keeping the harvested products under well-controlled conditions will help in restricting growth of pathogenic and postharvest spoilage microorganisms.

\section{References}

[1] Abdelnoor, A. M., Batshoun, R and Roumani, B. M. (1983). The bacterial flora of fruits and vegetables in Lebanon and the effect of washing on the bacterial content. Zbl. Bakt. Hyg., I. Abt. Orig. B. 177:342-349.

[2] Amoah, P., Drechsel, P., Abaidoo, R. C and Abraham, E. M. (2009): Improving food hygiene in Africa where vegetables are irrigated with polluted water. Regional Sanitation and Hygiene Symposium. 21: 3-5.

[3] Baker, F. J and Breach. M. R. (1980): Medical Microbiology Techniques ( $1^{\text {st }}$ ed.). Butter worths and co. (publishers) ltd. London. Pp 547.

[4] Beuchat, C. R. (1995). Pathogenic microorganisms associated with fresh produce. Journal of Food Protection. 59(2): 204-216.

[5] Beuchat, L. R. (1998). Pathogenic microorganisms associated with fresh produce. J. Food Prot. 59: 204-216.

[6] Beuchat, L. R. (2002). Ecological factors influencing survival and growth of human pathogens on raw fruits and vegetables. Microbes Infect. 4: 413-423.

[7] Buck, J. W., Walcott, R. R and Beuchat, L. R. (2003). Recent trends in microbiological safety.of fruits and vegetables. Plant Health Progress. 10: 1094.

[8] Carmo, L. S., Cummings, C., Linardi V. R., Dias, R. S., Souza, J. M., Sena, M. J., Santos, D. A., Shupp, J. W., Pereira, R. K and Jett, M. (2004): A case study of a massive Staphylococcal food poisoning incident. Foodborne Pathog.Dis. 1: 241-246.

[9] Cheesbrough, M. (2000): District laboratory practice in Tropical Countries. Part 2. Cambridge University Press. U.K. Pp 62-70.

[10] Clinical Laboratory Standard Institute, CLSI. (2009). Performance for antimicrobial susceptibility. $10^{\text {th }}$ edition. Vol 29: Pp1-3.

[11] Cowan, S. T. and steel, K.J. (1985): Manual for the identification of medical Bacteria. Cambridge University press. 45-60.

[12] Djoussé, L., Arnett, D. K., Coon, H., Province, M. A., Moore, L. L and Ellison, R. C. (2004): Fruit and vegetable consumption and LDL cholesterol: the National Heart, Lung, and Blood Institute Family Heart Study. American Journal of Clinical Nutrition. 79: 213-217.

[13] Fisher, T. L and Golden, D. A. (1998). Fate of Escherichia coli O157:H7 in ground apples used in cider production. J. Food Prot. 61:1372-1374.

[14] Fredlund, H., Back, E., Sjoberg, L and Tornquist, E. (1987). Watermelon as a vehicle of transmission of shigellosis. Scand. $H$. Infect. Dis., 19:219-219.

[15] Houang, E., Bodnaruk, P and Ahmet, Z. (1991). Hospital green salads and the effects of washing them. J. Hosp. Infect., 17:125131.

[16] John, J. H and Ziebland, S. (2004): Reported barriers to eating more fruit and vegetables before and after participation in a randomized controlled trial: a qualitative study. Health Edu. Res. 19: 165-74.

[17] Kalia, A and Gupta, R. P. (2006). Handbook of Fruit and Fruit processing. Blackwell publishing. Pp 3-28.

[18] Kudva, I. T., Blanch, K and Hovde, C. J. (1998). Analysis of Escherichia coli O157:H7 survival in ovine and bovine manure and manure slurry. Applied Environmental Microbiology. 64: 3166-3174. 
[19] Maboko, M. M. and Du Plooy, C. P. (2008). Evaluation of crisp head lettuce cultivars (Lactuca sativa L.) for winter production in a soilless production system. Afr. J. Plant Sci. 2(10): 113-117.

[20] Macklin, K. S., Hess, J. B., Bilgili, S. F and Norton, R. A. (2005) Bacterial levels of pine shavings and sand used as poultry litter. $J$. Appl. Poult. Res. 14:238-245.

[21] Mullins, G. L. (2002). An investigation in Poutry manure. Poultry Virginia Tech Pub. No. 424-434.

[22] Ofor, M. O., Okorie, V. C., Ibeawuchi, I. I., Ihejirika, G. O., Obilo, O. P and Dialoke, S. A. (2009): Microbial Contaminants in Fresh Tomato Wash Water and Food Safety Considerations in SouthEastern Nigeria. Life Sci. J.1:80-82

[23] Pell, A. N. (1997). Manure and microbes: public and animal health problem. J. Dairy Sci. 80:2673-2681.
[24] Ray, B and Bhunia, A. K. (2007). Fundamental Food Microbiology. 4th Edn.,CRC Press, USA., p 492.

[25] Riboli, E and Norat, T. (2003): Epidemiologic evidence of the protective effect of fruit and vegetables on cancer risk. Am. J. Clin. Nutr. 78: 559S-69S.

[26] Schefferle, H. E. (1995). The microbiology of built up poultry litter. J. Appl. Bacteriol. 28(3):403-411.

[27] Solomon, H. M., Kautter, D. A., Lilly, T and Rhodehamel, E. J. (1990). Outgrowth of Clostridium botulinum in shredded cabbage at room temperature under modified atmosphere. J. Food Prot., 53:831-833. 